\title{
Chemical composition and cardiovascular effects induced by the essential oil of Cymbopogon citratus DC. Stapf, Poaceae, in rats
}

\author{
Flávia V. Moreira, ${ }^{1}$ Joana F. A. Bastos, ${ }^{1}$ Arie F. Blank, ${ }^{2}$ Péricles B. Alves, ${ }^{3}$ \\ Márcio R. V. Santos",
${ }^{1}$ Departamento de Fisiologia, Centro de Ciências Biológicas e da Saúde, Universidade Federal de Sergipe, Av. Marechal Rondon s/n, Rosa Elze, 49.100-000 São Cristóvão-SE, Brasil, ${ }^{2}$ Departamento de Agronomia, Universidade Federal de Sergipe, Av. Marechal Rondon s/n, Rosa Elze, 49.100-000 São Cristóvão-SE, Brasil,
${ }^{3}$ Departamento de Química, Universidade Federal de Sergipe, Av. Marechal Rondon, s/n, Rosa Elze, \\ 49.100-000 São Cristóvão-SE, Brasil.
}

\begin{abstract}
RESUMO: "Composição química e efeitos cardiovasculares do óleo essencial de Cymbopogon citratus DC. Stapf, Poaceae, em ratos”. C. citratus é utilizada na medicina popular para tratar hipertensão. Este trabalho investigou a composição química e os efeitos cardiovasculares do óleo essencial do C. citratus (OECC). Foram identificados oito constituintes no OECC, sendo geranial o majoritário (43,08\%). Em ratos, o $\mathrm{OECC}(1,5,10$ e $20 \mathrm{mg} / \mathrm{kg}$, i.v.) induziu hipotensão e bradicardia que foram atenuadas pela atropina e tiopental sódico, mas não por L-NAME ou indometacina. Em anéis de artéria mesentérica de ratos pré-contraídos com fenilefrina, o OECC (1 a $3000 \mu \mathrm{g} / \mathrm{mL})$ induziu relaxamento que não foi afetado após remoção do endotélio, após TEA ou em anéis précontraídos com $\mathrm{KCl}(80 \mathrm{mM})$. Além disso, o $\mathrm{OECC}(1000 \mu \mathrm{g} / \mathrm{mL})$ não induziu efeito adicional sobre o relaxamento máximo da nifedipina $(10 \mu \mathrm{M})$. Em conclusão, o OECC induz hipotensão possivelmente devido à redução da resistência vascular que pode ser causada por inibição do influxo de $\mathrm{Ca}^{2+}$, e bradicardia provavelmente devido à ativação de receptores muscarínicos cardíacos.
\end{abstract}

Unitermos: Cymbopogon citratus, óleo essencial, efeitos cardiovasculares, ratos.

\begin{abstract}
Cymbopogon citratus DC. Stapf, Poaceae, is used in the folk medicine for hypertension treatment. This work investigated the chemical composition and cardiovascular effects in rats of $C$. citratus essential oil (EOCC). A phytochemical screening demonstrated the presence of eight constituents, being geranial the major compound (43.08\%). In rats, EOCC (1, 5,10 , and $20 \mathrm{mg} / \mathrm{kg}, i . v$.) induced transient hypotension and bradycardia that were attenuated by atropine and sodium thiopental, but not by L-NAME or indomethacin. In rings of rat superior mesenteric artery pre-contracted with phenylephrine, EOCC (1 to $3000 \mu \mathrm{g} / \mathrm{mL}$ ) induced relaxation that was not affected after removal of the endothelium, after TEA or in rings pre-contracted with $\mathrm{KCl}(80 \mathrm{mM})$. Furthermore, EOCC $(1000 \mu \mathrm{g} / \mathrm{mL})$ was not able to induce additional effect on maximal relaxation of nifedipine $(10 \mu \mathrm{M})$. In conclusions, EOCC induces hypotension, possibly by reduction in vascular resistance caused by inhibition of the $\mathrm{Ca}^{2+}$ influx, and bradycardia probably due to an activation of cardiac muscarinic receptors.
\end{abstract}

Keywords: Cymbopogon citratus, essential oil, cardiovascular effects, rats.

\section{INTRODUCTION}

The essential oils are a mixture of volatile substances composed mainly of terpenes in addition to some other non-terpene components. These volatile substances are commonly found in aromatic plants and their therapeutic potentials have been lately evaluated (Kris-Etherton et al., 2002; Edris, 2007; Paduch et al., 2007).

Studies in animals have demonstrated beneficial properties of essential oils in the cardiovascular system as antithrombotic, antiplatelet, endothelial protective, vasorelaxant and hypotensive activities (Lahlou et al., 2005; Edris, 2007). Recent reports have showed that cardiovascular effects of essential oils also occur in humans as improvement in coronary flow (Shiina et al., 2008) and hypotensive and bradycardic effects (Dayawansa et al., 2003).

Cymbopogon citratus (DC.) Stapf, Poaceae, is an aromatic medicinal plant popularly known as "capim- 
santo" and used in the folk medicine as anxyolitic and anti-hypertensive. Several pharmacological effects were studies such as: analgesic, sedative/hypnotic, anxiolytic, anticonvulsant (Viana et al., 2000; Blanco et al., 2009). Some studies have shown that the endovenous administration of aqueous and hydroalcoholic extracts of leaves of $C$. citratus present anti-hypertensive effect in rats (Carbajal et al., 1989; Singi et al., 2005).

Considering the lack of studies of essential oil of C. citratus (EOCC) on the cardiovascular system and it use in the folk medicine, the objective of this work was to evaluate the hypotensive and vasorelaxant effects of this oil in rats.

\section{MATERIALS AND METHODS}

Leaves of Cymbopogon citratus (DC.) Stapf, Poaceae, were collected from the garden of medicinal plants from Federal University of Sergipe (Brazil). A voucher specimen was deposited at Herbarium-ASE of Federal University of Sergipe, (code 9391). EOCC was obtained from the fresh leaves by hydrodistillation in a Clevenger apparatus for $8 \mathrm{~h}$ and stored at $4{ }^{\circ} \mathrm{C}$. When required, EOCC was dissolved in a saline/cremophor $(0.1 \% \mathrm{v} / \mathrm{v})$ solution, for in vivo experiments, or distilled water/cremophor $(0.1 \% \mathrm{v} / \mathrm{v})$ solution, for in vitro experiments, at desired concentrations.

The drugs used were: acetylcholine chloride (ACh), L-phenylephrine (Phe), NG-nitro-L-arginine methyl ester hydrochloride (L-NAME), atropine sulphate, indomethacin (INDO), tetraethylammonium (TEA) and cremophor (all from Sigma), sodium thiopental (Cristália), heparin sodium salt (Roche) and nifedipine (NIF) (RBI). The INDO was dissolved with sodium bicarbonate $\left(\mathrm{NaHCO}_{3}\right)$ to $2.5 \%$ in saline $(\mathrm{m} / \mathrm{v})$, while others drugs were freely dissolved in Tyrode solution or saline. All stock solutions were maintained at $0{ }^{\circ} \mathrm{C}$ and diluted to the desired concentration with Tyrode solution (in vitro experiments) or saline (in vivo experiments), when necessary. $\mathrm{NaHCO}_{3}$ and $\mathrm{EtOH}$ in used concentrations showed no effect on control experiments (data not shown).

EOCC was analyzed by gas chromatography coupled with mass spectrometry (GC/MS) according to these experimental conditions: capillary column DB-5MS (30m x $0.25 \mathrm{~mm} \times 0.25 \mathrm{~mm}$ i.d), electron impact $70 \mathrm{eV}$; helium $(99.999 \%)$ was used as carrier gas at a constant flow of $1.2 \mathrm{~mL} \mathrm{min-1}$ and an injection volume of $0.5 \mu \mathrm{L}$ (dilution in ethyl acetate); injector temperature $250{ }^{\circ} \mathrm{C}$; detector temperature $280{ }^{\circ} \mathrm{C}$. The oven temperature was programmed from $50{ }^{\circ} \mathrm{C}$ (isothermal for $2 \mathrm{~min}$ ), with an increase of $4{ }^{\circ} \mathrm{C} / \mathrm{min}$., to $200{ }^{\circ} \mathrm{C}$, then $10{ }^{\circ} \mathrm{C} / \mathrm{min}$ to 300 ${ }^{\circ} \mathrm{C}$, ending with a $10 \mathrm{~min}$ isothermal at $300{ }^{\circ} \mathrm{C}$. Mass spectra were taken at $70 \mathrm{eV}$; a scan interval of $0.5 \mathrm{~s}$ and fragments from 40 to $550 \mathrm{Da}$. Quantitative analysis of the chemical constituents was performed by flame ionization gas chromatography (FID), under same conditions GC-
MS. Identification of individual components of the essential oil was performed by computerized matching of the acquired mass spectra with those stored in NIST2 1 and NIST107 mass spectral library of the GC-MS data system. Retention indices (RI) for all compounds were determined according to literature (Van Den Dool \& Kratz, 1963) for each constituent as previously described (Adams, 2007).

Male Wistar rats (200-300 g) were used in all experiments. They were housed in conditions of controlled temperature $\left(21 \pm 1^{\circ} \mathrm{C}\right)$ and exposed to a $12 \mathrm{~h}$ light-dark cycle with free access to food (Purina-Brazil) and tap water. All procedures described in the present work are approved by the Animal Research Ethics Committee from Universidade Federal de Sergipe (CEPA n 31/2007).

The measurements of the mean arterial pressure (MAP) and heart rate (HR) were performed as described by Guedes et al. (2004). The MAP and HR were recorded before and after administration of $\operatorname{EOCC}(1,5,10$ and 20 $\mathrm{mg} / \mathrm{kg}, i . v$., randomly), and after treatment with atropine (2 $\mathrm{mg} / \mathrm{kg}$; i.v.; $15 \mathrm{~min}$.), L-NAME (20 mg/kg; i.v.; $30 \mathrm{~min})$, INDO $(5 \mathrm{mg} / \mathrm{kg}$, i.v. $30 \mathrm{~min})$ or sodium thiopental $(45 \mathrm{mg} /$ $\mathrm{kg}$; i.p., $60 \mathrm{~min}$ ), separately. The change of MAP and HR for each dose was expressed as percentage of baseline values.

For in vitro experiments, the rings of rat superior mesenteric artery (1-2 mm) were isolated and maintained according to the technique described by Santos et al. (2006).

The presence of functional endothelium was assessed by the ability of acetylcholine to evoke more than $70 \%$ of relaxation against phenylephrine-induced contraction.

Values were expressed as the mean \pm SEM. The results were analyzed or with repeated measures one or two-way ANOVA followed by Bonferroni post-test. The $\mathrm{pD}_{2}$ values were obtained by non-linear regression. All procedures were performed by using Graph Pad Prism $3.02^{\mathrm{TM}}$

\section{RESULTS AND DISCUSSION}

In Brazil, many hypertensive patients with associated cardiovascular diseases drink daily tea of Cymbopogon citratus, and this study demonstrated possible benefits of the essential oil extracted of this plant on the cardiovascular system. Our results demonstrated that OECC appears to have a calcium-blocking property as many drugs used in the treatment of hypertension such as amilodipine, nifedipine and verapamil (Sociedade Brasileira de Cardiologia, 2007).

The analysis of the EOCC by GC/MS demonstrated the presence of eight constituents that are showed in Table 1. The major constituents were geranial (43.08\%), neral (32.19\%) and mircene (17.58\%) (Table 1). The percentages obtained in the present work were similar to those demonstrated in other studies for the same species 
(Blanco et al., 2009; Guimarães et al., 2008). Furthermore, it did not find in the literature any study demonstrating the activity of these constituents on the cardiovascular system.

In non-anesthetized rats, the injections of EOCC $(1,5,10$ and $20 \mathrm{mg} / \mathrm{kg}$; i.v.) induced an intense and tran-

Table 1. Chemical composition of the essential oil of Cymbopogon citratus (DC.) Stapf, Poaceae, leaves

\begin{tabular}{lcc}
\hline \multicolumn{1}{c}{ Constituents } & $\mathrm{RI}^{\mathrm{b}}$ & $\%$ \\
\hline $\begin{array}{l}\text { 6-Methyl-5- } \\
\text { hepten-2-one }\end{array}$ & 982 & 0,57 \\
Mircene & 988 & 17,58 \\
Linalool & 1100 & 1,08 \\
Epoxide of & 1170 & 0,51 \\
rosefurano & & \\
Neral & 1239 & 32,19 \\
Geraniol & 1251 & 4,37 \\
Geranial & 1269 & 43,08 \\
Acetate of geraniol & 1379 & 0,62 \\
Total identified & & 100,00 \\
\hline
\end{tabular}

a Percentages obtained by FID peak-area normalization (DB-5 column); ${ }^{\text {}}$ Retention Indices (DB-5 column) sitory hypotension associated with bradycardia (Figure 1A).

It is established that the stimulation of cardiac muscarinic receptors from sinoatrial node by vagal action induces intense bradycardia, which can be followed by hypotension due to a decrease in cardiac output (Peterson et al., 1984). It is also well known that activation of endothelial muscarinic receptors induces intense vasodilatation due to release of endothelium-derived relaxing factors, mainly $\mathrm{NO}$ and $\mathrm{PGI}_{2}$ (Furchgott \& Zawadzki, 1980; Moncada \& Higgs, 1993). This activation can cause decrease in peripheral vascular resistance and, consequently, hypotension. The involvement of the muscarinic receptors in these responses was evaluated through experiments in the animals pre-treated with atropine $(2 \mathrm{mg} / \mathrm{kg})$, a nonselective antagonist of these receptors. In these animals, the hypotension was significantly attenuated only in dose of $20 \mathrm{mg} / \mathrm{kg}$, while bradycardia was completely abolished in the doses of 5, 10 and $20 \mathrm{mg} / \mathrm{kg}$ (Figure 1A). This suggests that the bradycardia seems to be caused by cardiac muscarinic activation.

In order to check a possible indirect effect of EOCC through of central nervous system and vagus nerve, we performed experiments by using rats anesthetized with sodium thiopental $(45 \mathrm{mg} / \mathrm{kg})$, a general anesthetic
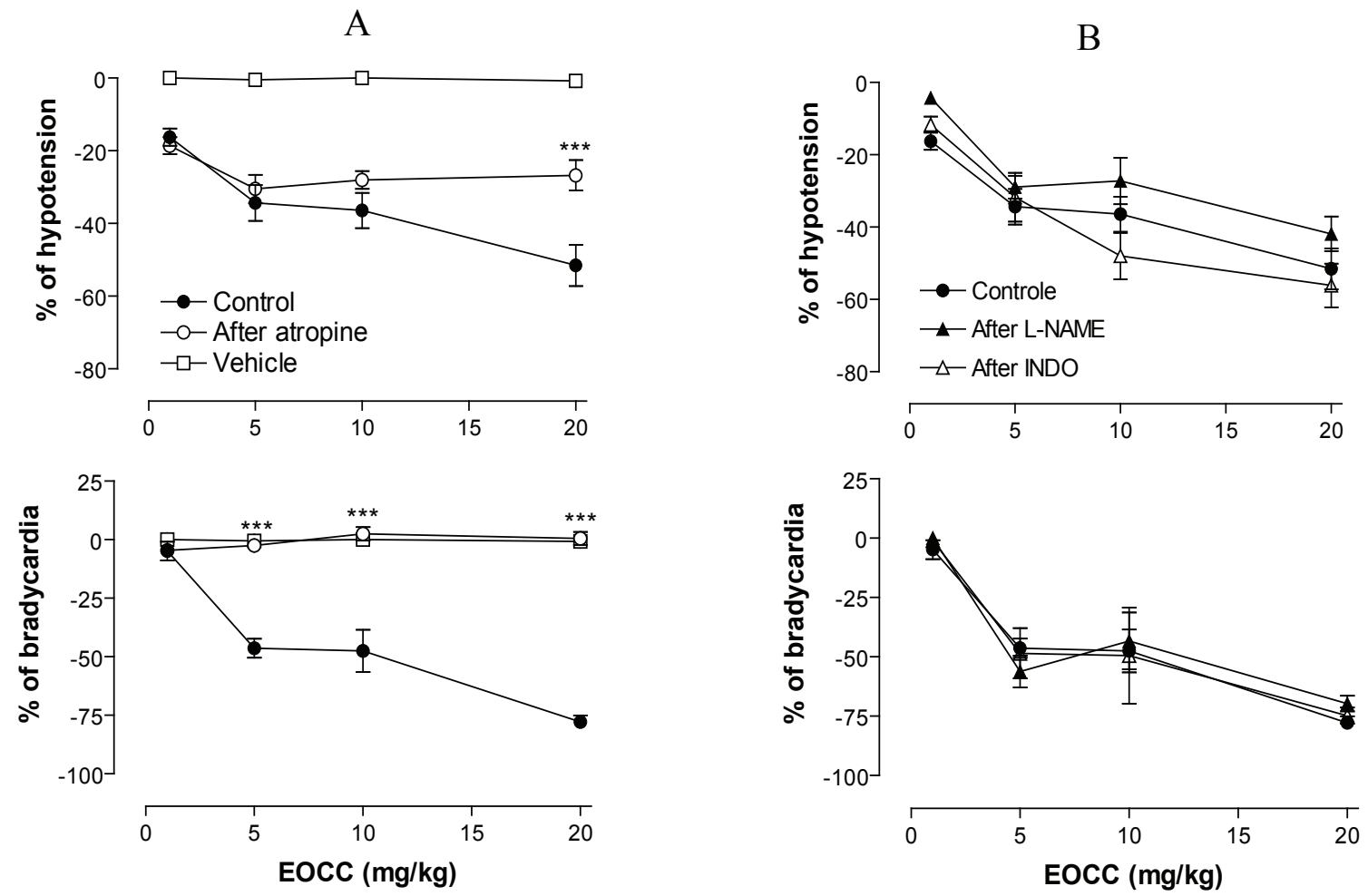

Figure 1. Hypotensive and bradycardic responses induced by in bolus administration of EOCC (1, 5, $10 \mathrm{and} 20 \mathrm{mg} / \mathrm{kg}$, i.v. $)$ or vehicle in non-anesthetized rats: A. before (control) and after pretreatment with atropine ( $2 \mathrm{mg} / \mathrm{kg}, i . v ., 15 \mathrm{~min})$; B. before (control) and after pretreatment with L-NAME (20 mg/kg, i.v., $30 \mathrm{~min})$ or INDO ( $5 \mathrm{mg} / \mathrm{kg}$, i.v., $30 \mathrm{~min})$. Values are mean \pm SEM of six experiments. To evaluate dose-dependence, it was used one-way ANOVA followed by Bonferroni post-test. To evaluate difference between groups, it was used repeated measures two-way ANOVA followed by Bonferroni post-test. ${ }^{*} \mathrm{p}<0.05,{ }^{* *} \mathrm{p}<0.01$ and ${ }^{* * *} \mathrm{p}<0.001$ vs Control. 
with vagolitic and central vasomotor depressant actions (Morgan et al., 2006). In this condition, only bradycardia was significantly attenuated in the doses of 5,10 and $20 \mathrm{mg} / \mathrm{kg}$ (Figure 2), suggesting that, at least in part, the bradycardia induced by EOCC appears to involve components of central nervous system.

Interestingly, despite the bradycardia has been completely abolished by atropine and attenuated by sodium thiopental, the hypotension induced by the doses of 5 and $10 \mathrm{mg} / \mathrm{kg}$ was not affected. Thus, the hypotension does not appear to be caused by decrease of cardiac output due to intense bradycardia and a possible decrease of the peripheral vascular resistance may also is contributing to the expression of this effect.

A possible role of the $\mathrm{NO}$ and $\mathrm{PGI}_{2}$ in the EOCCinduced hypotension was investigated. In animals treated with L-NAME $(20 \mathrm{mg} / \mathrm{kg})$, a nitric oxide (NO) synthase inhibitor (Moncada \& Higgs, 1993) or INDO $(5 \mathrm{mg} /$ $\mathrm{kg}$ ), an inhibitor of cyclooxygenase (COX) (Furchgott \& Zawadzki, 1980), the hypotension and bradycardia were
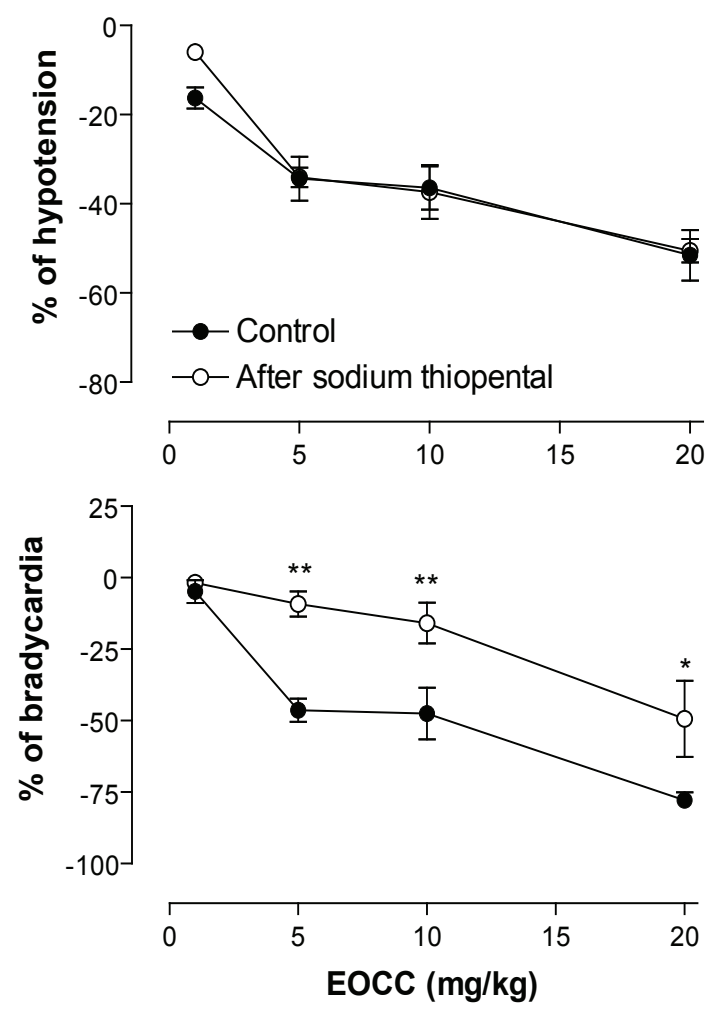

Figure 2. Hypotensive and bradycardic responses induced by in bolus administration of EOCC $(1,5,10$ and $20 \mathrm{mg} / \mathrm{kg}$, i.v. in non-anesthetized rats before and after sodium thiopental anesthesia $(45 \mathrm{mg} / \mathrm{kg}$, i.p., $30 \mathrm{~min})$. Values are mean $\pm \mathrm{SEM}$ of six experiments. The data were analyzed with repeated measures two-way ANOVA followed by Bonferroni post-test. " $p<0.05$, ${ }^{* *} \mathrm{p}<0.01$ and $^{* * *} \mathrm{p}<0.001$ vs Control. not significantly altered (Figure 1B), suggesting that NO and $\mathrm{PGI}_{2}$ appear not be participating of these effects.

To reinforce the hypothesis of that hypotensive response could be due to a decrease in peripheral vascular resistance caused by a possible vasorelaxation, we performed experiments in isolated rings of the rat superior mesenteric artery. In rings with intact endothelium, EOCC $(1-3000 \mu \mathrm{g} / \mathrm{mL})$ produced relaxations in concentrationdependent manner of tonus induced by $10 \mu \mathrm{M}$ of $\mathrm{Phe}\left(\mathrm{pD}_{2}=\right.$ $2.52 \pm 0.10 ; \mathrm{E}_{\max }=103 \pm 10 \% ; \mathrm{n}=6$ ). These vasorelaxations were not different of those obtained in the denudedendothelium rings $\left(\mathrm{pD}_{2}=2.34 \pm 0.15 ; \mathrm{E}_{\max }=107 \pm 4 \% ; \mathrm{n}=\right.$ 6) (Figure $3 \mathrm{~A}$ ), suggesting that this effect appears not to be mediated by endothelium.

These initial in vitro findings are in agreement with those obtained in the in vivo experiments, which demonstrated that hypotension induced by the EOCC appears not to be mediated by endothelial factors, such as $\mathrm{NO}$ or $\mathrm{PGI}_{2}$, but appears be caused by a vasodilatation. Furthermore, our results are analogous to others studies that had demonstrated that several essential oils present also a potent hypotensive effect through a direct vasorelaxant effect (Lahlou et al., 2005; Guedes et al., 2004).

It well known that the maintenance of smooth muscle contraction depends on $\mathrm{Ca}^{2+}$ influx from extracellular space through voltage and/or receptor operated calcium channels (VOCC and/or ROCC, respectively) (Karaki \& Weiss, 1988). It is well also reported that the increase of external $\mathrm{K}^{+}$concentration $(\mathrm{KCl} 80 \mathrm{mM})$ induces smooth muscle contraction through VOCC activation and subsequent calcium release from sarcoplasmic reticulum (Karaki \& Weiss, 1988). The high K+-induced contraction is inhibited by $\mathrm{Ca} 2+$ channel blockers or by removal of external $\mathrm{Ca} 2+$. This contraction is, therefore, entirely dependent Ca2+ influx (Karaki \& Weiss, 1988). Thus, we evaluated the EOCC effect on endothelium-denuded rings pre-contracted with $\mathrm{K}+$-depolarizing solution $(\mathrm{KCl}$ $80 \mathrm{mM}$ ). This set of experiments revealed that EOCC also induce vasorelaxations similarly to those obtained in rings pre-contracted with phenylephrine $\left(\mathrm{pD}_{2}=2.04 \pm 0.12 ; \mathrm{E}_{\max }\right.$ $=101 \pm 7 \% ; n=6$ ) (Figure 3B), which suggest that EOCC appears to be aging through the inhibition of the $\mathrm{Ca}^{+2}$ influx through VOCC.

Furthermore, in preparations without endothelium pre-contracted with Phe, EOCC $(1000 \mathrm{mg} / \mathrm{mL})$ did not induce an additional effect on the maximal vasorelaxation of NIF $(10 \mathrm{mM})$. Interestingly, the same was observed when NIF $(10 \mathrm{mM})$ was added on the maximal vasorelaxation of the EOCC $(1000 \mathrm{mg} / \mathrm{mL})$ (Figure 4), demonstrating that EOCC could be acting through a similar pathway of NIF, i.e., blocking dihydropyridine sensitive L-type VOCC (Hagiwara et al., 1993). Although the results show a majority participation of the $\mathrm{Ca}^{+2}$ channels, the possible involvement of $\mathrm{K}^{+}$channels can not be discarded.

According to the literature, potassium channels are the dominant ion conductive pathways in vascular 
A

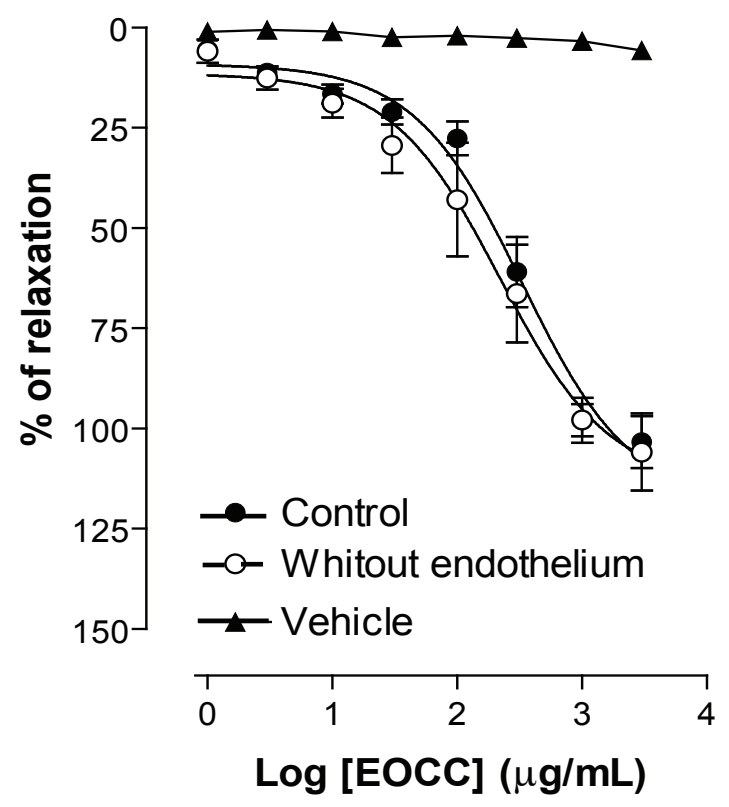

B

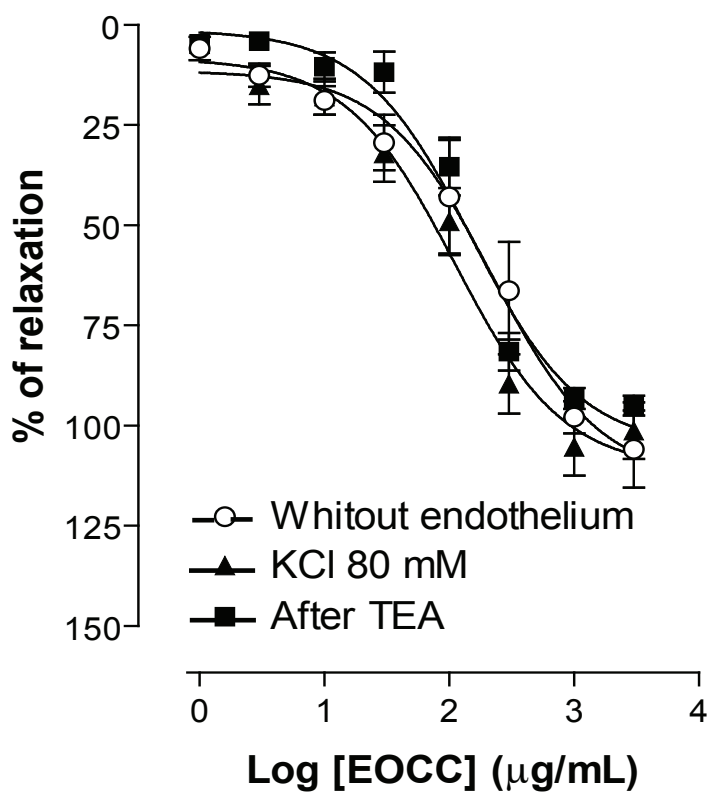

Figure 3. Vasorelaxant effect of EOCC (1-3000 $\mu \mathrm{g} / \mathrm{mL}$, cumulatively) or vehicle in rings of rat superior mesenteric artery: A. precontracted with Phe $(10 \mu \mathrm{M})$ in the control condition (with endothelium) and after removal of endothelium; B. without endothelium pre-contracted with Phe $(10 \mu \mathrm{M})$, pre-contracted with $\mathrm{KCl} 80 \mathrm{mM}$ or pre-contracted with Phe $(10 \mu \mathrm{M})$ after incubation with TEA $(0.1 \mathrm{mM}, 30 \mathrm{~min})$. Values are mean \pm SEM of six experiments. The data were analyzed with one-way ANOVA followed by Bonferroni post-test.

muscle cells. The electrochemical gradient for $\mathrm{K}^{+}$ions is such that opening of $\mathrm{K}^{+}$channels results in diffusion of this cation out of the cells and membrane hyperpolarization. This effect closes $\mathrm{Ca}^{2+}$ channels and leads to vasodilatation (Jackson, 2000).

Thus, the participation of the $\mathrm{K}^{+}$channels in the EOCC-induced vasorelaxation was investigated by using rings without functional endothelium, pre-contracted with Phe $(10 \mu \mathrm{M})$, in the absence or presence of $100 \mu \mathrm{M}$ of TEA, a non-selective blocker of these channels (Cook, 1989). In this condition, $\mathrm{EOCC}$ was able to induce relaxations $\left(\mathrm{pD}_{2}=2.18 \pm 0.08 ; \mathrm{E}_{\max }=105 \pm 4 \% ; \mathrm{n}=6\right)$ that was not significantly different of the control $\left(\mathrm{pD}_{2}=2.34 \pm 0.15 ; \mathrm{E}_{\max }\right.$ $=107 \pm 4 \% ; n=6)($ Figure $3 \mathrm{~B})$. This result suggests that $\mathrm{K}^{+}$channels do not seem to be involved in the vasorelaxant effect induced by the EOCC.

Take together, these results demonstrate that the EOCC induces hypotension associated to bradycardia in

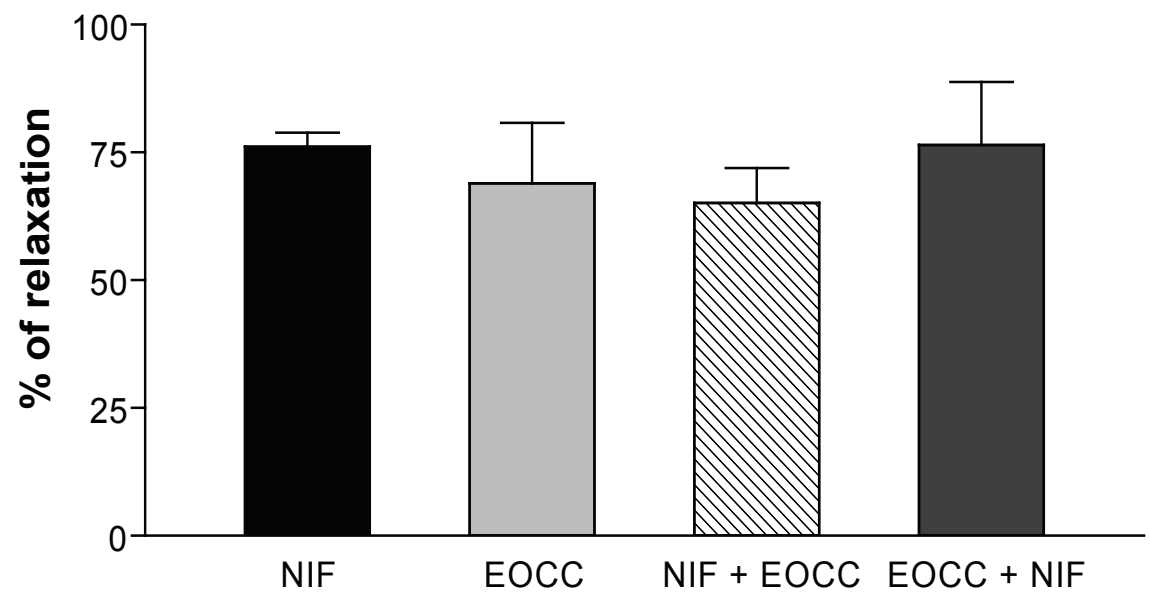

Figure 4. Vasorelaxant effect of NIF $(10 \mathrm{mM})$, EOCC $(1000 \mu \mathrm{g} / \mathrm{ml})$, EOCC $(1000 \mu \mathrm{g} / \mathrm{ml})$ after the maximum relaxation of NIF $(10$ $\mathrm{mM})$ and NIF $(10 \mathrm{mM})$ after the maximum relaxation of EOCC $(1000 \mu \mathrm{g} / \mathrm{mL})$ in rings of rat mesenteric artery without endothelium pre-contracted with Phe. Values are expressed as mean \pm SEM of six experiments. The data were analyzed with one-way ANOVA followed by Bonferroni post-test. 
normotensive non-anaesthetized rats. The hypotension appears to be caused by a decrease in peripheral vascular resistance, while bradycardia seems to be due to an activation of cardiac muscarinic receptors, involving, in part, compounds of central nervous system. Furthermore, the EOCC induces vasorelaxation in rat mesenteric artery possibly due to an inhibition of the $\mathrm{Ca}^{2+}$ influx through voltage-operated $\mathrm{Ca}^{2+}$ channels. This plant seems presents a potential clinical use for hypertension treatment, however, further studies are necessary to evaluate it safety and therapeutic margin before the human use.

\section{ACKNOWLEDGEMENTS}

We thank Mr Osvaldo Andrade Santos for the technical support. This work was supported by grants from FAPITEC-SE, CNPq, CAPES, Ministério da Saúde, SES/ SE, Brazil.

\section{REFERENCES}

Adams RP 2007. Identification of essential oil components by gas chromatograpy/mass spectroscopy. 4.ed. Illinois USA: Allured Publishing Corporation, Carol Stream.

Blanco MM, Costa CA, Freire AO, Santos JG Jr, Costa M 2009. Neurobehavioral effect of essential oil of Cymbopogon citratus in mice. Phytomedicine 16: 265-270.

Carbajal D, Casaco A, Arruzababala L, Gonzalez R, Tolon T 1989. Pharmacologycal study of Cymbopogon citratus leaves. J Ethnopharmacol 25: 103-107.

Cook NS 1989. Effect of some potassium channel blockers on contractile responses of the rabbit aorta. $J$ Cardiovasc Pharmacol 13: 299-306.

Dayawansa S, Umeno K, Takakura H, Hori E, Tabuchi E, Nagashima Y, Oosu H, Yada Y, Suzuki T, Ono T, Nishijo $\mathrm{H}$ 2003. Autonomic responses during inhalation of natural fragrance of cedrol in humans. Auton Neurosci 108: 79-86.

Edris AE 2007. Pharmaceutical and therapeutic potentials of essential oils and their individual volatile constituents: a review. Phytother Res 21: 308-323.

Furchgott RF, Zawadzki JV 1980. The obligatory role of endothelial cells in the relaxation of arterial smooth muscle by acetylcholine. Nature 288: 373-376.

Guedes DN, Silva DF, Barbosa-Filho JM, Medeiros IA 2004. Endothelium-dependent hypotensive and vasorelaxant effects of the essential oil from aerial parts of Mentha $\mathrm{x}$ villosa in rats. Phytomedicine 11: 490-497.

Guimarães LGL, Cardoso MG, Zacaroni LM, Lima RK 2008. Influência da luz e da temperatura sobre a oxidação do óleo essencial de capim-limão [Cymbopogon citratus (D.C.) Stapf]. Quim. Nova 31: 1476-1480.

Hagiwara S, Mitsui M, Karaki H 1993. Effects of felodipine, nifedipine and verapamil on cytosolic $\mathrm{Ca}^{2+}$ and contraction in vascular smooth muscle. Eur J Pharmacol 234: 1-7.

Jackson WF 2000. Ion channels and vascular tone. Hypertension

$$
\text { 35: 173-178. }
$$

Karaki H, Weiss GB 1988. Calcium release in smooth muscle. Life Sci 42: 111-122.

Kris-Etherton PM, Hecker KD, Bonanome A, Coval SM, Binkoski AE, Hilpert KF, AE Griel, Etherton TD 2002. Bioactive compounds in foods: their role in the prevention of cardiovascular disease and cancer. $\mathrm{Am} \mathrm{J}$ Med 113: 71S-88S.

Lahlou S, Magalhães PJC, Siqueira RJB, Figueiredo AF, Interaminense LFL, Maia JGS, Sousa PJ 2005. Cardiovascular effects of the essential oil of Aniba canelilla bark in normotensive rats. $J$ Cardiovasc Pharmacol 46: 412-421.

Moncada S, Higgs EA 1993. The L-arginine-nitric oxide pathway. New Eng J Med 29: 2002-2012.

Morgan GE Jr, Mikhail MS, Murray MJ 2006. Clinical Anesthesiology. 4.ed. The McGraw-Hill Companies.

Paduch R, Kandefer-Szerszeń M, Trytek M, Fiedurek J 2007. Terpenes: substances useful in human healthcare. Arch Immunol Ther Exp 55: 1-13.

Peterson GL, Herron GS, Yamaki M, Fulllerton DS, Schimerlik MI 1984. Purification of the muscarinic acetylcholine receptor from porcine atria. Proc Natl Acad Sci 81: 49934997.

Santos MRV, Nascimento NMS, Antoniolli AR, Medeiros IA 2006. Endothelium-derived factors and $\mathrm{K}^{+}$channels are involved in the vasorelaxation induced by Sida cordifolia L. in the rat superior mesenteric artery. Pharmazie 61: 466-469.

Sociedade Brasileira de Cardiologia 2007. V Diretrizes Brasileiras de Hipertensão Arterial. Arq Bras Cardiol 89: e24e79.

Shiina Y, Funabashi N, Lee K, Toyoda T, Sekine T, Honjo S, Hasegawa R, Kawata T, Wakatsuki Y, Hayashi S, Murakami S, Koike K, Daimon M, Komuro I 2008. Relaxation effects of lavender aromatherapy improve coronary flow velocity reserve in healthy men evaluated by transthoracic Doppler echocardiography. Int J Cardiol 129: 193-197.

Singi G, Damasceno DD, D'Andréa ED, Silva GA 2005. Efeitos agudos dos extratos hidroalcoólicos do alho (Allium sativum L.) e do capim-limão (Cymbopogon citratus (DC.) Stapf). Rev Bras Farmacogn 15: 94-97.

Van Den Dool H, Kratz PD 1963. A generalization of the retention index system including linear temperature programmed gas-liquid partition chromatography. J Chromatogr 11: 463-471.

Viana GSB, Vale TG, Pinho RSN, Matos FJA2000.Antinociceptive effect of the essential oil from Cymbopogon citratus in mice. J Ethnopharmacol 70: 323-327. 